\title{
Bir ölçek geliştirme çalışması: Kemoterapi uygulanan hastalarda özbakım yetersizliği kuramına gore özbakım davranışları ölçeği
}

\author{
Funda Karadağlı1, Şule Ecevit Alpar² \\ 1İstanbul Gelişim Üniversitesi Sağlık Bilimleri Yüksekokulu, Hemşirelik Bölümü,İstanbul \\ ${ }^{2}$ Marmara Ü, Sağlık Bilimleri Fakültesi Hemşirelik Bölümü, Hemşirelik Esasları AD, İstanbul
}

$\ddot{0} \mathbf{z}$

Amaç: Bu araştırmanın amacı, kemoterapi uygulanan hastalarda Orem'in Öz Bakım Yetersizliği Kuramı'na göre öz bakım davranışlarını ölçmeye yönelik bir ölçme aracı geliştirmektir. Yöntem: Araştırma, temel bir araştırma niteliğinde olup, İstanbul da Avrupa yakasında bulunan üç eğitim ve araștırma hastanesinde, araștırma kriterlerine uyan ve araştırmaya katılmayı kabul eden 600 hasta üzerinde, Ağustos 2016-Şubat 2017 tarihleri arasında gerçekleștirilmiştir. Verilerin toplanmasında Hasta Bilgi Formu ve araştırmacı tarafından geliştirilen taslak ölçek kullanılmıştır. Verilerin analizinde tanımlayıcı istatistikler,yapı geçerliliğ̆i için açımlayıcı faktör analizi yapılmıştır. Güvenirlik analizleri için, Cronbach Alpha ve Spearman-Brown korelasyon testleri kullanılmıştır. Bulgular:5'li likert tipi olan ölçeğin, 24 maddeden ve bireysel bakım,uyku düzeni,solunumu sürdürme,aktivite ve hareket,beslenme alışkanlığı ve sorunlarla başa çıkma olmak üzere 6 faktörden oluştuğu,açılklanan toplam varyansın \%64.75 olduğu saptanmıştır. Yapılan güvenirlik analizi sonucunda, ölçeğin Cronbach's alfa katsayısı 0.88 olarak hesaplanmıştır. Test-tekrar test güvenirliğini belirlemek için yapılan analizler sonucunda $(\mathrm{n}=30)$ ölçeğin iki uygulaması arasında yüksek düzeyde tutarlılık saptanmıştır (r:.945, p<0.001). Sonuç: Geliştirilmiş olan bu ölçeğin, geçerlik ve güvenilirliği oldukça yüksek, bireylerin öz bakım davranışlarını belirlemede güvenilir ve geçerli bir ölçme aracı olduğu belirlenmiştir.

Anahtar Kelimeler: Hasta, kanser, tedavi, öz bakım, ölçek geliştirme

\section{A Scale development study: Scale of self-care behaviors according to the theory of self-care deficiency in patients who were administered chemotherapy}

\begin{abstract}
Objective: The aim of this research was to develop a tool to measure self-care behaviors based on the Orem's Self-Care Deficiency Theory in patients who receive chemotherapy. Method: This basic research was conducted between on August 2016 and February 2017 on a total of 600 patients who met the research criteria and agreed to participate in the survey in İstanbul as well as three education and research hospitals in Europe. Data was collected via two instruments, namely the Patient information Form and the draft scale developed by the researcher. Descriptive statistics, exploratory factor analysis for construct validity were made for the data processing. Cronbach Alpha and Spearman-Brown correlation tests were employed for reliability analysis.
\end{abstract}

Yazının geliş tarihi:22.05.2017 Yazının kabul tarihi: 17.08.2017

Sorumlu Yazar: Funda Karadağll, Cihangir mah. Şehit Jandarma Komando Er Hakan Öner Sk. No:1 Avcllar/ İstanbul, Telefon: 021242270 00/416, E-posta: fkaradagli@gelisim.edu.tr 
Results: The results indicated that the scale had 24 items measured with a five-point Likert-type scale. The items were grouped under six factors, as; individual care, sleep regimen, respiratory maintenance, activity and movement, eating habits, coping with problems. They were accounted for $64.75 \%$ of the total variance. The scale had a Cronbach's alpha coefficient of 0.88 . As a result of the analysis to determine test-retest reliability $(n=30)$, it was found that the scale had high level of consistency between the mean scores of the two applications ( $\mathrm{r}: 945, \mathrm{p}<0.001$ ). Conclusion: This improved scale was found fairly high in terms of validity and reliability. Besides, it is found that it is a valid and reliable measurement tool to determine the self-care behaviors of the individuals.

Keywords: Patient, cancer, treatment, self care, scale development

\section{Giriş}

Kanser, vücudun bir organ veya dokusunda beliren bazı anormal hücrelerin kontrolsüz ve düzensiz bir şekilde yayılımı ile karakterize olan ve dünyada hemen her ülkede mortalite ve morbidite oranları açısından önde gelen bir sağlık sorunudur..-4 Kanser insidansındaki artışa paralel olarak günümüzde tüm yeni tedavi yaklaşımlarına karşın, halen kanserden ölümler gelişmiş toplumlarda ikinci sırada yer almaktadır.5-10

Kanser tedavisinde sıklıkla kullanılan kemoterapi, doğal veya sentetik kimyasal, biyolojik ajanlar ve hormonlarla yapılan bir tedavi şeklidir.2,11,12 İlaçlar, kanserli hücrelerin büyümesini, gelişmesini ve çoğalmasını önlerken aynı zamanda sağlıklı hücrelerin ölümüne de yol açabilir ve istenmeyen birçok yan etkiye neden olabilir.11,13 Tedavinin yarattığı yan etkiler hastaların yaşam kalitesini ve yaşamsal fonksiyonlarını olumsuz yönde etkileyerek öz bakım gereksinimlerini giderememelerine neden olabilmektedir. Bu nedenle kanser hastalarının tedaviye bağlı olan yan etkilere rağmen tedavi süresince ve tedavi sonrasında yaşam kalitelerinin iyileștirilmesi ve öz bakımlarının devamının sağlanması çok önemlidir.11,14

Öz bakım, yaşamı, sağlığı ve iyilik durumunu sürdürmek için bireyler tarafından başlatılan ve gerçekleștirilen etkinliklerdir. Öz bakım insanlarda kişisel merak, eğitim ve sağlık bakımından edinilen tecrübeler ile öğrenilmiş davranışlardır. ${ }^{15-17}$ Öz bakım kavramına ilişkin ilk tanımlamalar, 1800'lü yılların ortalarına dayanmakla birlikte günümüzde çoğunlukla Orem'e (2001) atfedilmektedir. ${ }^{17,18}$ Orem öz bakımı; bireyin sürekli, kontrollü, etkili ve amaçlı davranışlarının olgunlaşmasıyla kendi kendisine yaptığı bakım olarak tanımlamıștır ve temel insan gereksinimleri etkili şekilde karşılandı̆̆ı zaman öz bakım, bireyin sağlıklı olduğunu gösterir. ${ }^{18}$ Öz Bakım Eksikliği Hemşirelik Teorisi, sınırlılıkları nedeniyle öz bakımını yapamayan kişiyle ilgilidir. Bu teoriye göre hemşire, öz bakımını yapamayan bireye yardım eder, aile ve arkadaşlarına da ona nasıl yardım edeceklerini öğretir.18-20 Orem, hastalıktan korunma ve sağlığı geliştirme isteği için birey tarafından yapılması gerekli olan tüm öz bakım eylemlerini terapötik öz bakım gereksinimleri olarak tanımlar ve terapötik öz bakım gereksinimleri; evrensel öz bakım gereksinimleri, gelişimsel öz bakım gereksinimleri ve sağlıktan sapma durumlarındaki öz bakım gereksinimleri olmak üzere üç alt boyutta incelenmektedir.18 Evrensel öz bakım gereksinimleri insanın günlük yaşam aktiviteleri ile ilgili temel gereksinim ve istekleridir. Sağlıklı bir birey için gerekli olan sekiz evrensel öz bakım gereksinimi tanımlanmıştır. Bu gereksinimler; hava, su, beslenme, boşaltım, aktivite ve dinlenme, sosyal etkileşim, tehlikelerden korunma ve normal olmadır. Evrensel öz bakım gereksinimleri etkili bir şekilde karşılandığı zaman öz bakım sağlığı ve iyiliği destekler. ${ }^{18,19}$

Öz bakımını kendisi yapabilen birey, öz bakım gereksinimlerini yeterli ve uygun şekilde karşılayabilecek, kendi sağlığının sorumluluğunu alabilecek ve başkalarına bağımlı olmayacaktır. Ancak kendi öz bakımını tam veya yeterli düzeyde karşılayamayanlara yardım etmek gerekmektedir. Pek çok hemşire kuramcı gibi Orem' ${ }^{18}$ göre bu desteği sağlayacak kişi 
hemşiredir ve hemşire bireyin öz bakım gereksinimleri ile özel olarak ilgilenmelidir. Hemşire, yaşamın sürdürülmesi, sağlığın devamı, hastalıklar, travma ve bunların etkisiyle baş etmede ve sağlığını normalde olduğu durumuna döndürmede öz bakım gereksiniminin sağlanması ve yönetiminden sorumludur. ${ }^{16-18}$

Öz bakım davranışlarının değerlendirilmesi sunulan hizmetlerin geliştirilmesinde önemli ipuçları verebileceğinden, ayrıca hemşirelik bakımına ve gereksinimlerine yönelik fikir olușturabileceğinden son derecede önemlidir.1,21Değerlendirmede, bireyde istendik düzeyde öz bakımın gerçekleşip gerçekleșmediğinin somut bir göstergesi olarak "Öz Bakım Davranışları Ölçeği" bir yaklaşım olarak ele alınabilir. Orem'in kuramında yer alan evrensel öz bakım gereksinimleri dikkate alınarak geliştirilen bu ölçek ile kemoterapi uygulanan hastalarda öz bakım davranıșlarının belirlenmesi, hemşirelik bakımının ve öz bakım gereksinimlerinin hastane sürecinde ya da taburculuk sonrası istendik düzeyde karşılanması konusunda önemli olduğu düşünülmektedir. Yapılan araştırmalar sonucunda ülkemizde kemoterapi alan hastaların öz bakım davranışlarını ölçen spesifik bir ölçeğe rastlanmamıștır. Araştırmada; kemoterapi uygulanan hastaların Orem'in Öz Bakım Yetersizliği kuramına göre öz bakım davranışlarını ölçmeye yarayan geçerli ve güvenilir bir ölçek geliştirilmesi amaçlanmıştır.

\section{Gereç ve Yöntem}

\section{Araştırmanın Evren ve Örneklemi}

$\mathrm{Bu}$ araștırmanın amacı kemoterapi uygulanan hastaların Öz Bakım Yetersizliği Kuramına gore öz bakım davranışlarını ortaya koymaya yönelik birölçek geliştirmek olduğundan, araştırma temel araştırma niteliğindedir. Araştırmada en az 500 kişiye ulaşılması hedeflenmiștir. Comfrey ve Lee ${ }^{22}$, mutlak gözlem genişlikleri factor oluşumlarına gore şu şekilde sinıflandırmışlardır: 50-(çok zayıf), 100(zayıf), 200-(kararsız), 300-(iyi), 500-(çok iyi), 1000 ve yukarısı-(ideal).22 $\mathrm{Bu}$ çalışmanın verileri doktora tezinden alınmıș olup, aşağıda belirtilen çalışma kriterlerine uyan 600 kişi çalışmanın örneklemini oluşturmuştur.

\section{Çalışmaya Alınma Kriterleri}

- Kemoterapi ünitesinde tedavi görüyor olmak,

- Yeni tanı konmuş ve en az 3. kür ve üzeri kemoterapi tedavisi veriliyor olmak,

- Akciğer kanseri, meme kanseri, mide kanseri, kolon kanseri ve jinekolojik kanser tanısıyla 1 . seçenek kemoterapi tedavisi veriliyor olmak,

- 18 yaş ve üzerinde olmak,

- Araştırmaya katılmaya gönüllü olmak.

Çalışmadan Çıkartılma Kriterleri

- Veri formlarını eksik doldurmak,

- Hedef tedavi alıyor olmak,

- 2. ve üstü seçenek tedavi alıyor olmak,

- Radyoterapi alıyor olmak.

Araştırmanın Yapıldı̆̆ı Yer ve Tarih

Araștırma, İstanbul ilinde Avrupa yakasında bulunanüç eğitim ve araştırma hastanesinde Ağustos 2016-Şubat 2017 tarihleri arasında yapılmıştır.

Veri Toplama Araçları ve Verilerin
Toplanması

Araştırma verileri; hastaların kişisel
ve hastalığa ilişkin özelliklerini değerlendiren "Hasta Bilgi Formu" ve "Kemoterapi Uygulanan Hastalarda Öz Bakım Yetersizliği Kuramına Göre Geliştirilen Öz Bakım Davranışları Ölçeği Taslağı" kullanılarak toplanmıştır.

Hasta Bilgi Formu; literatür doğrultusunda araștırmacl tarafından hazırlanan, hastaların kişisel durumları (yaşı, cinsiyeti, medeni durumu, eğitim düzeyi, aile türü, sürekli yaşadı̆̆ı yer, gelir durumu, sosyal güvence varlığı, çalışma durumu, evde kiminle yaşadığı, bakmakla yükümlü olduğu kişi varlığı ve hayata bakışı) ve hastalığa ilişkin (bir kronik hastalığın varlığı, hastalığının tanısı, hastalığının ne zaman teşhis edildiği, daha önce kemoterapi tedavisi alma durumu, 
kaçıncı kemoterapi ilacını aldığı ve tedavi protokolü) 19 soru yer almaktadır.

\section{Kemoterapi Uygulanan Hastalarda} Öz Bakım Yetersizliği Kuramına Göre Öz Bakım Davranışları Ölçeği Taslağı; Kapsam geçerliği için 63maddeli taslak ölçek, İç Hastalıkları Hemşireliği Anabilim Dalı'ndan (AD) 4 öğretim üyesine, Hemşirelik Esasları AD'dan 3 öğretim üyesine, Cerrahi Hastalıkları Hemşireliği AD'dan 1 öğretim üyesine, alanında uzman 2 onkoloji hemşiresine ve 1 ölçme ve değerlendirme uzmanına iletilerek görüşleri alınmıștır. Uzman görüșlerinin elde edilmesinde "Uzman Değerlendirme Formu" kullanılmıștır. $\mathrm{Bu}$ form, uzman görüşü vermeyi kabul eden uzmanlara, e-mail yoluyla ulaştırılmıştır. Kapsam geçerliği çalışmasında uzman görüşlerinin değerlendirilmesi amacıyla Davis tekniği uygulanmıștır.23Davis tekniği, uzman görüşlerini (a)"Son derece uygun", (b) “Oldukça uygun”,(c)“Biraz uygun” ve (d) "uygun değil" şeklinde dörtlü derecelendirmektedir. Bu teknikte (a) ve (b) seçeneğini işaretleyen uzmanların sayısı toplam uzman sayısına bölünerek maddeye ilişkin kapsam geçerlik indeksi (KGİ) elde edilmiştir. Taslak ölçeğin KGİ değerleri 0.60 ve 1.00 arasında bulunmuştur. Uzman görüşlerine bağlı olarak sorunlu olduğu ifade edilen maddelerin, öneriler doğrultusunda düzeltmeleri yapılmış ve uzman görüşleri önerileri ile 1 madde de eklenerek toplam 64 maddeden oluşturulan ölçek taslağı oluşturulmuştur. Esas uygulamaya başlamadan önce araştırmacı tarafından pilot uygulama yapılmıştır.

Pilot çalışma verileri, toplam 30 hastaya uygulanmıştır. Pilot uygulama esnasında hastaların anlamakta güçlük çektikleri sorularla ilgili gerekli düzeltmeler yapılmıștır. Pilot çalışma sonucunda ölçek maddelerinin değerlendirilmesiyle birlikte toplam 65 maddeden oluşan ölçeğe ulaşılmıştır ve sonrasında esas uygulamaya geçilmiştir. Yapı geçerliği, madde analizleri ve iç tutarlılık analizleri sonucunda yeniden düzenlenen taslak ölçek kararlılık bağlamındaki güvenirlik kat sayısını saptamak amacıyla test-tekrar test yöntemi kullanılarak 30 hastaya 2 hafta ara ile tekrar uygulanmıştır.
Ölçek, "5" Her zaman ile "1" Hiçbir zaman arasında değerlendirilen Likert tipinde bir ölçektir. Ölçekte belirlenen olumsuz sözlerin yanıtları "Her zaman: 1 " ile "Hiçbir zaman: 5" arasında ters yönde yeniden (recode) kodlanmıştır.Ölçekten alınabilecek maksimum puan 120 , minimum puan 24'tür. Ölçekten alınan puan arttıkça bireylerin öz bakım davranışları da olumlu yönde artmaktadır.

Verilerin toplanmasinda yapılandırılmış öz bildirime dayalı yöntemler kullanılmıştır. Araștırma verileri ayaktan kemoterapi ünitesine bașvuran hastalarla yapılan yüz-yüze görüşme yöntemiyle elde edilmiștir.

\section{Araştırmanın Etik Yönü}

Araștırmanın uygulanabilmesi ve verilerin toplanabilmesi için İstanbul İli Bakırköy Kamu Hastaneleri Birliği ve İstanbul ili Fatih Bölgesi Kamu Hastaneleri Birliği Genel Sekreterliğinden yazılı izin ve Marmara Üniversitesi Sağlık Bilimleri Enstitüsü Etik Kurulu'ndan, 28/03/2016 tarihli oturumun 5 sayılı kararı ile gerekli Etik Kurul Onayı alınmıştır. Çalışmaya katılmak isteyen, anket ve ölçeği yanıtlamayı kabul eden ve yazılı onam veren hastalar ile çalışma yürütülmüştür.

\section{Verilerin Değerlendirilmesi}

Geçerlik, ölçülmek istenilen değişkenin başka değişkenlerle karıştırılmadan ölçülebilmesini, diğer ifadeyle amacına hizmet etme derecesini ifade etmektedir. Ölçme aracının yapı geçerliği, aracın ölçülmek istenen davranış bağlamında soyut bir kavramı (faktörü) doğru bir şekilde ölçebilme derecesini göstermektedir. Ölçme aracının yapı geçerliliğinde kullanılan yol faktör analizidir. ${ }^{24-26}$

Taslak ölçeğin yapı geçerliği analizi için, SPSS (Statistical Package for the Social Sciences) programında faktör analizi testleri [KMO, Bartlett Testi, Anti-İmaj Korelasyon, Temel Bileşenler Analizi (Principal Components Analysis) ve Varimax Döndürme Yöntemi (Varimax Rotation)] kullanılarak yapılmıștır. Varimax döndürme yöntemi eksenlerin konumlarını değiştirmeden, yani $90^{\circ}$ lik açı ile döndürme 
yöntemidir. Faktörlerin birbirinden bağımsız olması nedeniyle en sık tercih edilen yöntemdir. ${ }^{24}$ Ayrıca sonuçların genellenebilirliği ve uygulamaların tamamına yakınında yorumlamada kolaylık sağlaması nedeniyle dik döndürme yöntemi tercih edilmiştir.

Güvenirlik, bireylerin test maddelerine verdikleri cevaplar arasındaki tutarlılı̆̆ı ve kullanılan ölçeğin ilgilenilen sorunu ne derece yansittığını ifade etmektedir. ${ }^{24}$ Ölçeğin güvenirlik çalışmaları kapsaminda, Spearman-Brown korelasyon (Shapiro-Wilk testi p değeri<0.05), Cronbach Alpha ve kararlılık bağlamındaki güvenirlik kat sayısını saptamak amacıyla test-tekrar test yöntemi kullanılmıștır.

\section{Bulgular}

\section{Bireylerin Demografik Özelliklerine İlişkin Bulgular}

Yaș ortalaması $55.67 \pm 12.42(20-83)$ olan bireylerin \%62.8'i kadın, \%81.7'si evli, \%64.3'ü ilköğretim mezunudur. Bireylerin çoğu (\%89.8) çalışmamakta, \%51.7'si ev hanımı ve \%79.8'i geniş aileye sahiptir. Katılımcların \%84.5'i gelirini orta düzeyde algllamakta olup \%98.8'i sosyal güvenceye sahiptir. Bireylerin \%93'ü İstanbul içinde ikamet etmekte, \%53'ü evde eş ve çocuklarıyla yaşamakta ve \%95.7'sinin bakmakla yükümlü olduğu kişi bulunmamaktadır. Katılımcıların çoğunun (\%80.5) hayata bakış açısı, "her zaman olumlu düșünen bir insandım, hala öyleyim" şeklindedir.Çalışmayakatılanbireylerinhasta lıksürecineilişkinözellikleriniincelediğimizd e; \%33.3'ünün kronik hastalığı olduğu ve $\% 20$ 'sinin akciğer kanseri, \%20'sinin meme kanseri, \%20'sinin mide kanseri, \%20'sinin kolon kanseri, \%20'sinin jinekolojik kanser tanısına sahip olduğu bulunmuştur. Hastaların \%25.2'sinin hastalığı Ağustos 2016 yılında teşhis edilmiştir. Çalışmaya katılan bireylerin hastalık sürecine ilişkin özellikleri incelendiğinde; bireylerin tedavisinin \%39.2'sinin 3. kür olduğu, \%32.7'sinin ise 4. kür olduğu saptanmış olup \%20.7'sinde Karboplatin-Paklitaksel, \%17.3'ünde Paklitaksel ve \%15.7'sinde ise
Adriamisin-Siklofosfamid tedavi protokolü kullanıldığı saptanmıştır.

\section{Madde Analizi ve Ölçeğin Faktör Yapısına İlişkin Bulgular}

Yapı geçerlik analizi yapılmadan önce ölçeğin madde analizi yapılmış ve ölçekte yer alan 65 maddenin maddetoplam puan korelasyonlarına bakılmıştır. Ölçekteki maddelerin korelasyon katsayllarının $\quad r=0.00$ ile 0.66 arasında olduğu, 25 maddenin $(1,6,7,19,20,21,24$, $25,27,29,30,36,38,43,49,50,51,53,55$, $57,58,59,60,64,65)$ madde-toplam korelasyon değerlerinin $r=0.31$ ile 0.66 arasında, pozitif yönde ve istatistiksel olarak anlamlı düzeyde olduğu, 40 maddenin $(2,3$, $4,5,8,9,10,11,12,13,14,15,16,17,18$, $22,23,26,28,31,32,33,34,35,37,39,40$, $41,42,44,45,46,47,48,52,54,56,61,62$, 63) ise madde-toplam korelasyon değerlerinin istatistiksel olarak anlaml olmakla birlikte $r=0.00$ ile 0.29 arasında olup istenilen düzeyden düşük olduğu saptanmıştır. Tavşancl ${ }^{25}$ ve Büyüköztürk ${ }^{24} \mathrm{e}$ göre madde-toplam korelasyonu0.30 ve daha yüksek olan maddeler ölçülecek olan özelliği en iyi derecede ayırt etmektedir. Bu nedenle analiz sonucunda $r=0.30$ altında olan 40 maddenin ölçekten çıkarılmasına karar verilmiş ve ölçek madde sayısı $25^{\prime}$ e düşmüștür.

Taslak ölçeğin Kaiser-Meyer Olkin (KMO) katsayısı0.81 ve Barlett testi sonucu $\mathrm{X}^{2}=10177.860 ; \mathrm{p}=0.000$ olarak çok ileri düzeyde anlamlı bulunmuştur $(\mathrm{p}<0.001)$. Anti-imaj $r$ değerleri=0.55-0.95 arasındadır. İlk faktör analizine toplam 25 madde ile başlanmıştır. İlk analizde döndürme işlemi yapılmamış ve ölçeğin 6 alt boyuttan oluştuğu görülmüştür. Ancak bu ilk analizde; 24. maddenin birden fazla boyutta yer aldığı ve yer aldığı faktörlerdeki değerlerin aralarındaki farkın 0.10'dan küçük olması nedeniyle ölçekten çıkarılmasına karar verilmiştir. Maddelerin birden fazla faktöre girmemesi, birden fazla faktöre girmesi dahilinde alınabilecek ölçüt faktör yükleri arasında en az 0.10 fark olmasıdır. İki faktördeki yük değerleri arasında 0.10 'dan az fark olan maddeler binişik maddeler olarak adlandırılmaktadır. ${ }^{24,25} \mathrm{Bu}$ işlemin ardından 
varimax dik döndürme tekniği kullanılarak 24 madde ile 2. faktör analizi yeniden yapılmış ve 24 maddelik ölçeğin son halinde 6 alt boyutta toplandığ görülmüş ve her bir alt boyuta giren maddeler incelendiğinde, alt boyutların mantıklı bir şekilde gruplaştıkları görülmüştür.

Şekil 1'de verilen faktörlere (alt boyutlara) ait özdeğer çizgi grafiği (screeplot) incelendiğinde, grafik eğrisinin hızlı düşüş gösterdiği nokta altıncı faktörün olduğu yerdir. Altıncı faktörden sonra eğrinin aynı doğrultuda ilerlediği görülmektedir. Buradan ölçekteki faktör sayısının altıda kalması gerektiği düşüncesine ulaşılmıştır. Ölçeğin faktör analizi sonucu elde edilen alt boyutların özdeğerleri ve açıkladıkları varyans miktarları Tablo 1'de verilmiștir.

Tablo 1'de görüldügü gibi, oluşan altı faktörün açıklanan toplam varyans miktarı \%64.755'tir. Faktörlerin açıkladıkları varyans miktarlarına bakıldığında sırasıyla; birinci faktörün \%27.839'unu, ikinci faktörün \%10.306'sını, üçüncü faktörün \%8.143'ünü, dördüncü faktörün \%7.221'ini, beşinci faktörün \%6.661'ini ve altıncı faktörün ise \%4.586'sını açıkladığı belirlenmiştir. Faktör analizi sonucunda ölçekte kalmasına karar verilen maddelerin faktörlere dağılımı ile factor yükleri Tablo 2'de gösterilmiştir.

Scree Plot

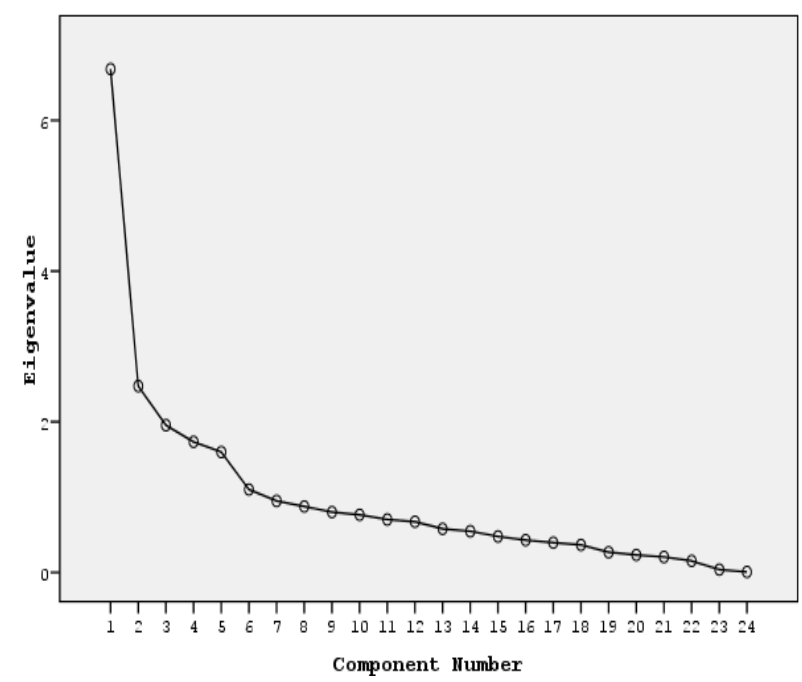

Şekil-1: Scree Sınaması
Tablo 1. Oluşan faktörler ve açıkladıkları toplam varyans miktarları

\begin{tabular}{|c|c|c|}
\hline Faktör & Özdeğer & Kümülatif \% \\
\hline 1 & 27.839 & 27.839 \\
\hline 2 & 10.306 & 38.145 \\
\hline 3 & 8.143 & 46.288 \\
\hline 4 & 7.221 & 53.509 \\
\hline 5 & 6.661 & 60.169 \\
\hline 6 & 4.586 & 64.755 \\
\hline $\begin{array}{l}\text { V } \\
\text { kullanıla } \\
\text { dağılımıı } \\
\text { 1'den b } \\
\text { maddele } \\
\text { edilebilir } \\
\text { madde } \\
\text { madde } \\
\text { görülmü } \\
\text { değer } \\
\text { maddele } \\
\text { 0.40 ve } \\
\text { Tablo } 3\end{array}$ & \multicolumn{2}{|c|}{$\begin{array}{l}\text { Dik Döndürme Tekniği } \\
\text { maddelerin faktörlere } \\
\text { ldığında ölçeğin Eigen değeri } \\
\text { faktörde toplandı̆̆ tüm } \\
\text { irdikleri faktörde kabul } \\
\text { leğerlerine sahip (en düşük } \\
\text { eğerinin 0.40; en yüksek } \\
\text { değerinin 0.97) olduğu } \\
\text { irden fazla faktörde yüksek } \\
\text { bir madde bulunmayıp, } \\
\text { tör yüklerinin değerlerinin } \\
\text { casında olduğu saptanmıstır }\end{array}$} \\
\hline
\end{tabular}

$\mathrm{Bu}$ aşamadan sonra her bir faktöre giren ölçek maddeleri incelenmiş ve alt boyutlar isimlendirilmiştir. $\mathrm{Bu}$ çerçevede; birinci faktör "Bireysel bakım", ikinci faktör "Uyku Düzeni", üçüncü faktör "Solunumu Sürdürme", dördün cüfaktör "Aktivite ve Hareket", beșinci faktör "Beslenme Alışkanlıkları", altıncı factor ise "Sorunlarla Başa Çıkma” olarak isimlendirilmiştir (Tablo 4). 
Tablo 2. Açıllanan toplam varyans miktarları

Faktör Yüklerinin Döndürülmüș

\begin{tabular}{|c|c|c|c|c|c|c|c|c|c|c|c|}
\hline \multirow[t]{2}{*}{ Faktörler } & \multicolumn{3}{|c|}{ Başlangıç özdeğerleri } & \multicolumn{4}{|c|}{ Toplam Faktör Yükleri } & \multicolumn{4}{|c|}{ Toplamları } \\
\hline & $\frac{\Xi}{\pi}$ & 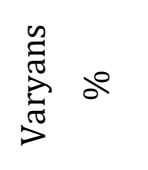 & 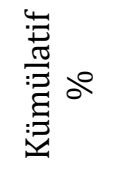 & $\begin{array}{l}\frac{\Xi}{\pi} \\
\frac{0}{2} \\
\stackrel{0}{\varphi}\end{array}$ & 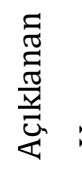 & 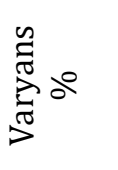 & 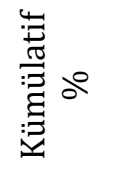 & $\begin{array}{l}\frac{\Xi}{\pi} \\
\frac{\pi}{2} \\
\stackrel{0}{\circ}\end{array}$ & 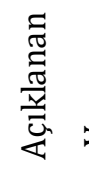 & 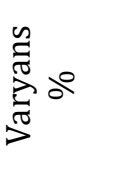 & 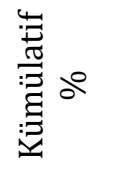 \\
\hline 1 & 6.681 & 27.839 & 27.839 & 6.681 & & 27.839 & 27.839 & 2.892 & & 12.050 & 12.050 \\
\hline 2 & 2.473 & 10.306 & 38.145 & 2.473 & & 10.306 & 38.145 & 2.812 & & 11.716 & 23.766 \\
\hline 3 & 1.954 & 8.143 & 46.288 & 1.954 & & 8.143 & 46.288 & 2.771 & & 11.545 & 35.311 \\
\hline 4 & 1.733 & 7.221 & 53.509 & 1.733 & & 7.221 & 53.509 & 2.545 & & 10.603 & 45.914 \\
\hline 5 & 1.599 & 6.661 & 60.169 & 1.599 & & 6.661 & 60.169 & 2.358 & & 9.825 & 55.740 \\
\hline 6 & 1.101 & 4.586 & 64.755 & 1.101 & & 4.586 & 64.755 & 2.164 & & 9.015 & 64.755 \\
\hline 7 & 0.949 & 3.955 & 68.710 & & & & & & & & \\
\hline 8 & 0.875 & 3.647 & 72.358 & & & & & & & & \\
\hline 9 & 0.801 & 3.336 & 75.693 & & & & & & & & \\
\hline 10 & 0.765 & 3.189 & 78.882 & & & & & & & & \\
\hline 11 & 0.702 & 2.926 & 81.808 & & & & & & & & \\
\hline 12 & 0.672 & 2.802 & 84.610 & & & & & & & & \\
\hline 13 & 0.578 & 2.410 & 87.020 & & & & & & & & \\
\hline 14 & 0.547 & 2.279 & 89.300 & & & & & & & & \\
\hline 15 & 0.477 & 1.988 & 91.288 & & & & & & & & \\
\hline 16 & 0.429 & 1.788 & 93.076 & & & & & & & & \\
\hline 17 & 0.395 & 1.645 & 94.721 & & & & & & & & \\
\hline 18 & 0.365 & 1.522 & 96.243 & & & & & & & & \\
\hline 19 & 0.268 & 1.117 & 97.360 & & & & & & & & \\
\hline 20 & 0.232 & 0.966 & 98.325 & & & & & & & & \\
\hline 21 & 0.205 & 0.855 & 99.181 & & & & & & & & \\
\hline 22 & 0.153 & 0.637 & 99.818 & & & & & & & & \\
\hline 23 & 0.038 & 0.157 & 99.975 & & & & & & & & \\
\hline 24 & 0.006 & 0.025 & 100.000 & & & & & & & & \\
\hline
\end{tabular}


Tablo 3. Faktör analizi sonrası dönüştürülmüş bileşenler matriksi

\begin{tabular}{|c|c|c|c|c|c|c|}
\hline & \multicolumn{6}{|c|}{ Alt Boyutlar } \\
\hline & 1 & 2 & 3 & 4 & 5 & 6 \\
\hline Madde64 & 0.763 & & & & & \\
\hline Madde43 & 0.759 & & & & & \\
\hline Madde36 & 0.617 & & & & & \\
\hline Madde49 & 0.593 & & & & & \\
\hline Madde58 & & 0.851 & & & & \\
\hline Madde20 & & 0.842 & & & & \\
\hline Madde38 & & 0.793 & & & & \\
\hline Madde7 & & 0.766 & & & & \\
\hline Madde55 & & & 0.871 & & & \\
\hline Madde27 & & & 0.854 & & & \\
\hline Madde50 & & & 0.682 & & & \\
\hline Madde51 & & & 0.670 & & & \\
\hline Madde57 & & & & 0.858 & & \\
\hline Madde65 & & & & 0.856 & & \\
\hline Madde19 & & & & 0.544 & & \\
\hline Madde60 & & & & 0.491 & & \\
\hline Madde29 & & & & & 0.856 & \\
\hline Madde30 & & & & & 0.830 & \\
\hline Madde1 & & & & & 0.547 & \\
\hline Madde53 & & & & & 0.458 & \\
\hline Madde25 & & & & & 0.407 & \\
\hline Madde6 & & & & & & 0.971 \\
\hline Madde21 & & & & & & 0.970 \\
\hline Madde59 & & & & & & 0.449 \\
\hline
\end{tabular}


Tablo 4. Kemoterapi uygulanan hastalarda öz bakım yetersizliği kuramına göre öz bakım davranışları ölçeği ve alt faktör değerleri

\begin{tabular}{|c|c|c|}
\hline \multicolumn{2}{|c|}{ Alt Faktör Dağılımı } & $\begin{array}{l}\text { Faktör } \\
\text { Değeri }\end{array}$ \\
\hline \multicolumn{3}{|c|}{ Faktör 1. Bireysel Bakım $(\alpha=0.75)$} \\
\hline \multicolumn{2}{|c|}{$\begin{array}{l}\text { Madde 64* (23) Günlük ihtiyaçlarımı karşılarken mutlaka birine ya da yardımcı bir araca } \\
\text { ihtiyaç duyarım. }\end{array}$} & 0.763 \\
\hline \multicolumn{2}{|c|}{ Madde 43 (13) Vücut temizliğimi rahatlıkla yapabilirim } & 0.759 \\
\hline \multicolumn{2}{|c|}{ Madde 36 (11) Gün boyunca bir sandalyede ya da koltukta oturma ihtiyacı duyarım. } & 0.617 \\
\hline \multicolumn{2}{|c|}{ Madde 49 (14) Hastalığım günlük yaşantımı sürdürmemi engellemiyor. } & 0.593 \\
\hline \multicolumn{3}{|c|}{ Faktör 2. Uyku Düzeni $(\alpha=0.87)$} \\
\hline \multicolumn{2}{|c|}{ Madde 58 (20) Uykuya dalmada ve sürdürmede güçlük çekerim } & 0.851 \\
\hline \multicolumn{2}{|c|}{ Madde 20 (5) Geceleri deliksiz uyurum } & 0.842 \\
\hline \multicolumn{2}{|c|}{ Madde 38 (12) Gece en az 6-8 saat uyumaya özen gösteririm. } & 0.793 \\
\hline \multicolumn{2}{|c|}{ Madde 7 (3) Sabah uykudan kalktığımda kendimi dinlenmiş hissederim. } & 0.766 \\
\hline \multicolumn{3}{|c|}{ Faktör 3. Solunumu Sürdürme $(\alpha=0.88)$} \\
\hline \multicolumn{2}{|c|}{ Madde 55 (18) Aktivite sırasında rahat nefes alıp verebilirim. } & 0.871 \\
\hline \multicolumn{2}{|c|}{ Madde 27 (8) Günlük işlerimi yaparken rahatlıkla nefes alıp verebilirim. } & 0.854 \\
\hline \multicolumn{2}{|c|}{ Madde 50 (15) Rahatlıkla merdiven çıkabilirim } & 0.682 \\
\hline \multicolumn{2}{|c|}{ Madde 51 (16) Rahatlıkla merdiven inebilirim } & 0.670 \\
\hline \multicolumn{3}{|c|}{ Faktör 4. Aktivite ve Hareket $(\alpha=0.78)$} \\
\hline \multicolumn{2}{|c|}{$\begin{array}{l}\text { Madde } 57 \text { (19) Haftada en az üç kez } 20 \text { dakika veya daha uzun süreli yürüyüş ya da egzersiz } \\
\text { yaparım. }\end{array}$} & 0.858 \\
\hline \multicolumn{2}{|c|}{$\begin{array}{l}\text { Madde } 65 \text { (24) Günlük spor aktivitelerine (Yüzme, yürüme ve bisiklete binme vb.) } \\
\text { katılabilirim. }\end{array}$} & 0.856 \\
\hline \multicolumn{2}{|c|}{$\begin{array}{l}\text { Madde } 19 \text { (4) Farklı etkinliklere (güne gitme, halk eğitim merkezlerine katılma, sinemaya } \\
\text { gitme vb.) katılırım. }\end{array}$} & 0.544 \\
\hline \multicolumn{2}{|c|}{ Madde 60 (22) İşimle ilgili görevlerimi yerine getirebilirim. } & 0.491 \\
\hline \multicolumn{3}{|c|}{ Faktör 5. Beslenme Alışkanlığı $(\alpha=0.66)$} \\
\hline \multicolumn{2}{|c|}{ Madde 29 (9) Sebzeyi önerilen miktarda tüketmeye özen gösteririm. } & 0.856 \\
\hline \multicolumn{2}{|c|}{ Madde 30 (10) Meyveyi önerilen miktarda tüketmeye özen gösteririm. } & 0.830 \\
\hline \multicolumn{2}{|c|}{ Madde 1 (1) Günde üç ana üç ara öğün yerim. } & 0.547 \\
\hline \multicolumn{2}{|c|}{ Madde 53 (17) Balık eti tüketmeye özen gösteririm. } & 0.458 \\
\hline \multicolumn{2}{|c|}{ Madde 25 (7) Kırmızı et tüketmeye özen gösteririm. } & 0.407 \\
\hline \multicolumn{3}{|c|}{ Faktör 6. Sorunlarla Başa Çıkma $(\alpha=0.78)$} \\
\hline \multicolumn{2}{|c|}{$\begin{array}{l}\text { Madde } 6(2) \quad \text { Benzer sorunu olan kişilerle sorunlarımı paylaşarak deneyimlerinden } \\
\text { yararlanırım. }\end{array}$} & 0.971 \\
\hline \multicolumn{2}{|c|}{ Madde 21 (6) Kendi problemlerime benzer problemleri olan hastalarla görüşürüm } & 0.970 \\
\hline \multicolumn{2}{|c|}{$\begin{array}{l}\text { Madde } 59 \text { (21) Kendimi endişeli ve stresli hissettiğim durumlarda bana yakın olan kişilerden } \\
\text { veya bir uzmandan destek alırım. }\end{array}$} & 0.449 \\
\hline
\end{tabular}

*Parantez dışındaki numaralar, 65 maddelik taslak ölçeğe ait madde numaralarıdır.

Kemoterapi Uygulanan Hastalarda Öz Bakım Yetersizliği Kuramına Göre Öz Bakım Davranışları Ölçeği Toplam $(\alpha=0.88)$ 


\section{İç Tutarlılık Analizi}

Güvenirlik kapsamında iç tutarlılığı test etmek için Chronbach Alpha değerlerine bakılmıştır. Ölçeğin toplam Cronbach Alpha değeri 0.88 olarak belirlenmiştir. Ölçeğin alt boyutlarının ise Cronbach Alpha değerleri, 1. Faktör (Bireysel Bakım) 0.75, 2. Faktör (Uyku Düzeni) 0.87, 3. Faktör (Solunumu Sürdürme) 0.88, 4. Faktör (Aktivite ve Hareket) 0.78, 5. Faktör (Beslenme Alışkanlığı) 0.66, 6. Faktör (Sorunlarla Başa Çıkma) 0.78 olarak bulunmuştur (Tablo 4).

Ölçeğin ve alt boyutlarının arasındaki ilişki Spearman-Brown korelasyon analizi tekniği ile değerlendirilmiş olup ölçeğin toplam puan ve tüm alt boyut puanları arasında istatistiksel açıdan $(\mathrm{p}<0.001)$ pozitif yönde anlamlı ilişki bulunmuştur (Tablo 5).

Ölçeğin zamana gore değişmezliğini değerlendirmek için test tekrar test yapılmış olup, ölçek, ölçek evreninden 30 hastaya 2 hafta ara ile uygulanmıştır. İlk uygulamada ölçeğin ortalama değeri $83.23 \pm 9.51$, ikinci uygulamada ise $81.73 \pm 9.96$ olarak bulunmuştur. Test tekrar test sonucunda korelasyonların oldukça yüksek olduğu görülmüştür ( $\mathrm{r}: 0.945, \mathrm{p}<0.001$ ).

Tablo 5. Ölçeğin toplam puan ve alt boyut puanları arasındaki korelasyon sonuçları $(n=600)$

\begin{tabular}{|c|c|c|c|c|c|c|c|}
\hline Değişkenler & $\begin{array}{c}\text { Toplam } \\
\text { Puan** } \\
\text { r }\end{array}$ & $\begin{array}{l}\text { Bireysel } \\
\text { Bakım** } \\
\quad r\end{array}$ & $\begin{array}{c}\text { Uyku } \\
\text { Düzeni** } \\
\text { r }\end{array}$ & $\begin{array}{c}\text { Solunumu } \\
\text { Sürdürme** } \\
\text { r }\end{array}$ & $\begin{array}{c}\text { Aktivite ve } \\
\text { Hareket** } \\
\text { r }\end{array}$ & $\begin{array}{c}\text { Beslenme } \\
\text { Alışkanlığ }{ }^{*} \\
{ }_{*}^{*} \\
\text { r }\end{array}$ & $\begin{array}{c}\text { Sorunlarla } \\
\text { Başa } \\
\text { Çlkma** } \\
\text { r }\end{array}$ \\
\hline $\begin{array}{l}\text { Toplam } \\
\text { Puan }\end{array}$ & -- & $0.731^{* *}$ & $0.651^{* *}$ & $0.739 * *$ & $0.758^{* *}$ & $0.614^{* *}$ & $0.359^{* *}$ \\
\hline $\begin{array}{l}\text { Bireysel } \\
\text { Bakım }\end{array}$ & $0.731^{* *}$ & --- & $0.300^{* *}$ & $0.491^{* *}$ & $0.565^{* *}$ & $0.384^{* *}$ & $0.316^{* *}$ \\
\hline $\begin{array}{l}\text { Uyku } \\
\text { Düzeni }\end{array}$ & $0.651^{* *}$ & $0.289 * *$ & --- & $0.309 * *$ & $0.328^{* *}$ & $0.306^{* *}$ & $0.300^{* *}$ \\
\hline $\begin{array}{l}\text { Solunumu } \\
\text { Sürdürme }\end{array}$ & $0.739 * *$ & $0.491^{* *}$ & $0.309^{* *}$ & --- & $0.509^{* *}$ & $0.339^{* *}$ & $0.310^{* *}$ \\
\hline $\begin{array}{l}\text { Aktivite ve } \\
\text { Hareket }\end{array}$ & $0.758^{* *}$ & $0.565^{* *}$ & $0.328^{* *}$ & $0.509 * *$ & --- & $0.330^{* *}$ & $0.310^{* *}$ \\
\hline $\begin{array}{l}\text { Beslenme } \\
\text { Alışkanlığı }\end{array}$ & $0.614^{* *}$ & $0.384^{* *}$ & $0.306^{* *}$ & $0.339 * *$ & $0.330^{* *}$ & --- & $0.380^{* *}$ \\
\hline $\begin{array}{l}\text { Sorunlarla } \\
\text { Bașa Cılkma }\end{array}$ & $0.359^{* *}$ & $0.316^{* *}$ & $0.300^{* *}$ & $0.310^{* *}$ & $0.310^{* *}$ & $0.380^{* *}$ & -- \\
\hline
\end{tabular}

${ }^{* *} \mathrm{p}<0.001$ 
Ölçeğin

Değerlendirilmesi

Puanlanması

Ölçek, "5" Her zaman ile "1" Hiçbir zaman arasındadeğerlendirilen Likert tipinde bir ölçektir. Ölçekte belirlenen olumlu cümlelerin yanitları "Her Zaman:5", "Sıklıkla:4", "Bazen:3", "Nadiren:2", "Hiçbir Zaman:1" olarak, olumsuz cümlelerin yanıtları ise "Her zaman:1" ile "Hiçbir zaman:5" arasinda ters yönde yeniden (recode) kodlanmıştır. Olumsuz maddelerin numaraları 36 (11), 58 (20) ve 64 (23)'dür. Ölçekten alınabilecek toplam puan 24 ile 120 arasında değișmektedir. Ölçekten alınan puan arttıkça bireylerin özbakım davranışları da olumlu yönde artmaktadır.

\section{Tartışma}

Ölçek geliştirme çalışmasına öncelikle literatürdeki benzer çalışmaların taranması ile başlanmıştır. Yapılan araştırmalar sonucunda ülkemizde kemoterapi alan hastaların öz bakım davranışlarını ölçen spesifik bir ölçeğe rastlanmamıştır. Özellikle geliştirilmiş olan bu ölçeğin kemoterapi uygulanan hastalarda öz bakım davranışlarını belirlemesi, hemşirelik bakımının ve öz bakım gereksinimlerinin hastane sürecinde ya da taburculuk sonrası istendik düzeyde karşılanması ve buna yönelik bakım geliştirilmesi hususundaçok önemli olduğu düşünülmektedir.

Yeni geliştirilen bir ölçeğin, geçerlik ve güvenirlik olan iki önemli özelliği yerine getirmesi istenir. Geçerlik, bir testin veya ölçeğin ölçmek istediği özelliği gerçekten ölçüp ölçmemesi ile ilgili bir kavramdır. Bu bağlamda bir ölçek ölçmek istediği özelliği tam ve doğru bir biçimde, diğer özelliklerle karıştırmadan ölçüyor ise buölçeğin geçerli olduğu söylenir. ${ }^{23}$ Geçerli bir ölçekte olması gereken önemli diğer bir özellik ise, ölçeğin güvenilir olmasıdır. Güvenirlik, bireylerin ölçek maddelerine verdikleri cevaplar arasındaki tutarlılık olarak tanımlanmaktadır. ${ }^{24}$

Geçerliğin sınanması için. $\mathrm{Bu}$ çalışmada, içerik-kapsam geçerliği ve yapı geçerliği kullanılmıştır. Kapsam geçerliği, ölçeği oluşturan maddelerin, ölçülmek istenen davranışı ölçemede nitelik ve nicelik olarak yeterli olup olmadığının göstergesidir. Kapsam geçerliğini test etmede kullanılan mantıksal yollardan biri, uzman görüşüne başvurmaktır. ${ }^{24} \mathrm{Bu}$ amaçla ölçeğin maddeleri, kapsam geçerliği için uzman görüşülerine sunulmuş ve kapsam geçerliğini uzman görüşlerinin değerlendirilmesi amacıyla Davis tekniği uygulanmıştır. Tekniğin kapsam geçerlik indeksiolarak 0.80 değeri ölçüt olarak kabul edilmektedir. ${ }^{23}$ Ölçekte KGI değerleri 0.60 ve 1.00 arasında bulunmuştur. Uzman görüşlerine bağlı olarak sorunlu olduğu ifade edilen maddelerin, öneriler doğrultusunda düzeltmeleri yapılmış ve uzman görüşleri önerileri ile 1 madde de eklenerek toplam 64 maddeden oluşturulan ölçek taslağı oluşturulmuştur. Bir ölçekte yer alacak maddeler, alan taraması yapılıp tasarlandıktan sonar bir ön incelemeden geçirilmiş ve gerekli görülen düzeltmeler yapılmış olsa bile, henüz hastaya uygulanacak safhada değildir. ${ }^{26} \mathrm{Bu}$ nedenle genel uygulamaya geçilmeden önce, ölçeğin maddeleri üzerinde farkedilmemiş herhangi bir imla, ifade veya biçim sorunu olabileceği sayıltısına bağlı olarak 30 kemoterapi hastasına araştırmacı tarafından pilot uygulama yapılmıştır. Pilot çalışma verileri, toplam 30 hastaya yüzyüze görüşme yöntemi kullanılarak uygulanmış olup, ölçeğin maddelerinin anlaşılırlığı, niteliği, yönergesi, kullanışlılığı, amaca uygunluğu ve yanıtlama şekli konusunda ayrıntılı değerlendirmeler alınmıştır ve geribildirimler sonucunda anlaşılmayan cümleler üzerinde gerekli düzenlemeler yapılmıştır. Pilot çalışma sonucunda ölçek maddelerinin değerlendirilmesiyle birlikte toplam 65 maddeden oluşan ölçeğe ulaşılmıştır. Son durumda 65 madde olarak yeniden düzenlenen taslak ölçeküzerinde yapı geçerliliği analizleri yapılmıştır.

Ölçeğin yapı geçerliği için açımlayıcı faktör analizi yapılmıștır. Ancak bu analizin yapılmasından önce örneklemin yeterli olup olmadığının test edilmesi gerekmektedir. Bunun için Kaiser-Meyer-Olkin (KMO) ve Barlett testi kullanılmıştır. KMO, faktör analizinde örneklem büyüklüğünün yeterliliğinde, Barlett testi ise değişkenler arasında yeterli oranda ilişki olup 
olmadığını göstermede kullanılır. KaiserMeyer-Olkin (KMO) gözlenen korelasyon katsayıları büyüklüğü ile kısmi korelasyon katsayılarının büyüklüğünü karşılaştıran bir indekstir. KMO "0 ile 1" arasında değişir. 1'e yaklaşması istenir. İyi bir faktör analizi için KMO ölçüsünün 0.80 'den fazla olması beklenir. Barlett testinde ise p değeri 0.05 anlamlılık derecesinden düşük ise değişkenler arasında faktör analizi için yeterli düzeyde ilişki olduğunu gösterir.27 Büyüköztürk (2016) ise faktörleştirilebilirlik için KMO'nun 0.60'dan yüksek çıkmasının yeterli olduğunu vurgulamaktadır. ${ }^{24} \mathrm{KMO}$ ile ölçeğin genel olarak faktör analizine uygunluğu ölçülürken, her bir sorunun faktör analizine uygunluğu, Anti-image korelasyonu ile ölçülmektedir ve bu değerin 0.50 'den az olmaması gerektiğini ve değerin 0.50 'den az olması durumunda bu sorunun analizden çıkarılması gerektiği önerilmektedir. ${ }^{28} \mathrm{Bu}$ çalışmada KMO değerinin 0.81, Barlett testinde $p$ değerinin 0.00 olması ve anti-imaj $r$ değerlerinin 0.55-0.95 arasında bulunması ölçeğin faktör analizi için uygun olduğunu göstermektedir. Tüm bu sonuçlardan sonra açımlayıcı faktör analizi yapılmış olup bu analiz, değişkenler arasındaki ilişkilerden hareketle faktör bulmaya yönelik bir işlemdir ve aynı yapıyı ya da niteliği ölçen değişkenleri biraraya getirerek ölçmeyi az sayıda faktör ile açımlamayı amaçlayan bir istatistiksel tekniktir. ${ }^{24}$ Ilk faktör analizine toplam 25 madde ile başlanmıştır. Ancak bu ilk analizde; 24. maddenin birden fazla boyutta yer aldığı ve yer aldığı faktörlerdeki değerlerin 0.10 'dan küçük olduğunun saptanması nedeniyle ölçekten çıkarılmasına karar verilmiştir. Birden fazla faktörde yer alan değerlerin yük değerleri arasındaki farkın en az 0.10 olması önerilir. ${ }^{24}$ Genellikle bir maddenin faktör yük değerinin 0.45 ya da daha yüksek olması seçim için iyi bir ölçüdür. Fakat bu değerin 0.30'a kadar indirgenmesi kabul görmektedir.24,2724 madde ile yapılan faktör analizi sonucunda ölçeğin maddelerinin öz değeri 1'den büyük 6 alt faktörden oluştuğu saptanmıştır ve girdikleri faktörde kabul edilebilir yük değerlerine sahip (en düşük madde yük değerinin 0.40 ; en yüksek madde yük değerinin 0.97) oldukları görülmüștür (Tablo 3). Elde edilen 6 alt faktörde toplanan ölçeğin toplam varyans miktarı \% 64.755'tir (Tablo 1, Tablo 2). Bir ölçeğin toplam varyans oranları ne kadar yüksek ise, ölçeğin faktör yapısının güçlü olması da o kadar yüksektir. Literatürde, maddelerin ortak faktör varyanslarının 1.00 'a ve 0.66 'ın üzerinde olması önerilmektedir ancak uygulamada bunu karşılamanın zor olması nedeniyle yapılan analizlerde faktör yüklerinin toplam varyansı açıklama yüzdesinin 40 ile 60 arasında olması yeterli kabul edilmektedir. ${ }^{24,29}$

Güvenirlik, ölçeğin ölçmek istediği niteliği ne oranda doğru ölçtüğünü ve bireylerin ölçek maddelerine verdikleri cevaplar arasındaki tutarlılığı gösterir. Güvenirlik zamana göre değişmezlik ölçüsüdür ve bir testin geçerliğini etkileyen bir unsurdur. Her geçerli bir ölçek güvenilirdir, ancak her güvenilir bir ölçek geçerli olmayabilir.24,27,29 Güvenirlik için iç tutarlılığı ölçmede en sık kullanılan yöntemlerden biri Cronbach alfa katsayısının hesaplanmasıdır. Alfa katsayısı ne kadar yüksekse, ölçeğinde iç tutarlılığının o kadar yüksek olduğu söylenebilir. Literatürde, alfa katsayısının 0.60-0.80 arasında olmasının ölçeğin güvenilirliğini kanıtladığı, $\quad 0.80-1.00$ arasında olmasının ölçeğin yüksek güvenirliğe sahip olduğunu gösterdiği bildirilmektedir. ${ }^{27}$ Geliştirdiğimiz bu ölçeğin Cronbach Alfa değeri 0.88 bulunmuş olup bu değer, ölçeğin güvenilir olduğunu göstermektedir.

Ölçümlerin dış tutarlığını saptamada kullanılan ikinci bir yaklaşım ise test tekrar test yöntemidir. Bu yöntem, bir testin aynı gruba belli aralıklarla iki kez uygulanmasıyla elde edilen puanlar arasındaki korelasyonun hesaplanmasıdır. Hesaplanan bu sayı güvenirlik katsayısı olarak kabul edilir. Bu sayı +1'e ne kadar çok yakınsa güvenirlik de o kadar yüksektir. ${ }^{24,27} \mathrm{Bu}$ çalışmada test tekrar testten elde edilen korelasyonun oldukça yüksek olduğu görülmüştür (r:0.945, $\mathrm{p}<0.001$ ). Ölçekten alınan ön ve son puanlar arasında benzerlik olması ve korelasyon sayısının +1'e yakın olması, ölçeğin güvenilir olarak kullanılabileceğini göstermektedir. 
Bu çalışma kapsamında, kemoterapi uygulanan hastalarda öz bakım davranışlarının belirlenmesine yönelik geçerli ve güvenilir bir ölçek geliştirilmiştir. Elde edilen bulgular kemoterapi uygulanan hastalarda, bireysel bakım, uyku düzeni, solunumu sürdürme, aktivite ve hareket, beslenme alışkanlığı ve sorunlarla başa çıkma konularındaki davranışlarını belirlemede ölçeğin uygun niteliklerde olduğunu göstermiştir. Geliştirilen bu ölçek, bireylerin öz bakım davranışlarının değerlendirilmesinde ve gerekli olan hemşirelik bakımının sunulmasında son derecede önem taşımaktadır. Diğer yandan literatürde benzer bir ölçeğin bulunmaması sebebiyle bu çerçevede yürütülecek çalışmalar için geliştirilen ölçek referans teşkil edecektir.

\section{Kaynaklar}

1. Ertem G., Kalkım A., Bulut S., Sevil Ü. Radyoterapi Alan Hastaların Evde Bakım Gereksinimleri ve Yaşam Kaliteleri. Maltepe Üniversitesi Hemşirelik Bilim ve Sanatı Dergisi 2009;2(2):3-12.

2. Prutipinyo C., Maikeow K., Sirichotiratana N. Self-CareBehaviours of Chemotherapy Patients. J Med Assoc Thai 2012;95:30-37.

3. Başak Ş.C. Üniversite Öğrencilerinde Meme Kanseri Bilgi Seviyesi: Geniş Kapsamlı Meme Kanseri Bilgi Testi'nin Geçerlik ve Güvenirlik Çalışması.Yüksek Lisans Tezi,Ahmet Tosun, Yayınlanmamış Tez, İstanbul, 2015.

4. Rocha L.S.,Beuter M., Neves E.T., Leite M.T., Brondani C.M., Perlini N.M.O.G. SelfCare Of Elderly Cancer Patients Undergoing Outpatient Treatment. Text Context Nursing, Florianópolis 2014;23(1):29-37.

5. National Cancer İnstitute. Cancer statistics. Erişim yeri: https://www.cancer.gov/about cancer/understanding/statistics, Erişim tarihi: 05.12.2016.

6. World Health Organization. World Cancer Day $2017 . \quad$ Erișim yeri:http://www.who.int/cancer/en/Erişim tarihi: 19.05.2017.
7. Hacıkamiloğlu E., Karaca M.Z., Gültekin M. Onkoloji Hemşireliği, Türkiye'de Kanser Kontrolü, 1. Basım, İstanbul,Nobel Tıp Kitabevleri Ltd. Şti, 2014:3-5.

8. Türkiye Halk Sağlığı Kurumu Kanser Daire Başkanlığı. 2014 Yılı Türkiye Kanser İstatistikleri.Erişim yeri: http://www.who.int/cancer/en/Erişim tarihi: 19.05.2017.

9. Perry M.C. Siciencefic Basis of Cancer Chemotherapy, M.C. Perry, The Chemotherapy Source Book. 4. ed. Philedelpia, LipincotWiliams\&Wilkings, 2008:1-7.

10. Aslan F.E., Olgun N., Uzun Ö. Kanserde Tedavi. Karadakovan A., Aslan F.E, Dahili ve Cerrahi Hastalıklarda Bakım, 2. baskı, Adana Nobel Kitabevi, 2011: 213-228.

11. Büker N., Şen F. Onkoloji Hastasında Kemoterapi ve Bakım. Can G., Onkoloji Hemşireliği, 1. basım, İstanbul, Nobel Tıp Kitabevleri Ltd. Ști, 2014:205-213.

12. Pekmezci H. Kanser Hastalarına Verilen Eğitimin Kemoterapi Semptomlarına Etkisi. Karadeniz Teknik Üniversitesi Sağlık Bilimleri Enstitüsü, Yüksek Lisans Tezi, Sevilay Hintistan, Yayınlanmamış tez, Trabzon, 2013.

13. DeVita V.T.,Chu E., Chu J. A History of Cancer Chemotherapy. Cancer Research, 2008;68:(21).Erișim

yeri:http://www.cancer.gov/aboutcancer/what-is-cancer.

14. Murphy B.A., Beaumont J.L., Isitt J., Garden A.S., Gwede C.K., Trotti A.M., Meredith R.F., Epstein J.B., Le Q.T., Brizel D.M., Bellm L.A., Wells N., Cella D. MucositisRelated Morbidity And Resource Utilization İn Head And Neck Cancer Patients Receiving Radiation Therapy With Or Without Chemotherapy. J Pain Symptom Manage 2009;38(4):522-532.

15. Velioğlu P. Hemşirelikte Kavram ve Kuramlar. 1. Basım, İstanbul, Akademi Basın ve Yayıncllık, 1999.

16. Karataș H, Öztürk C. Orem'in Öz Bakım Yetersizlik Kuramı ve Posttravmatik Epilepside Hemşirelik Bakımı. Atatürk Üniversitesi Hemşirelik Yüksekokulu Dergisi 2008;11(2). 
17. Kılıçgün M.Y. Özbakım Becerilerinde Ebeveyn Desteği Envanterinin Geliștirilmesi ve Standardizasyonu. Ahi Evran Üniversitesi Kırşehir Eğitim Fakültesi Dergisi (Kefad) 2013;14(3): 19-36.

18. Orem D.E. Self-care deficit theory of nursing: concepts and applications. 7th ed., USA: Mosby-Year Book, 2001:99-135.

19. Kızılcı S.,Avdal E.Ü. Diyabet ve Özbakım Eksikliği Hemșirelik Teorisinin Kavram Analizi. DEUHYO ED 2010; 3(3):164-168.

20. Fawcett J. Contemporary Nursing Knowledge: Analysis And Evaluation of Conceptual Modelsof Nursing. 2th ed., USA: FA Davis Comp, 2005: 223-319.

21. Yeşilbalkan Ö.U., Akyol A.D, Çetinkaya Y., Altın T., Ünlü D. Kemoterapi Tedavisi Alan Hastaların Tedaviye Bağlı Yaşadıkları Semptomlar ve Yaşam Kalitesine Olan Etkisinin İncelenmesi. Ege Üniversitesi Hemşirelik Yüksek Okulu Dergisi 2005; 21:13-31.

22. Comfrey A.L., Lee H.B.A. First Course in Factor Analysis. 1st ed., Hillsdale, NJ: Lawrence Erlbaum Associates, 1992.
23. Davis L.L. Instrument review: Getting the most from a panel of experts. Applied Nursing Research 1992;5:194-197.

24. Büyüköztürk Ş. Sosyal bilimler için veri analizi el kitabı. Ankara, Pegem Akademi, 2016.

25. Tavşancıl E. Tutumların ölçülmesi ve SPSS ile veri analizi. Ankara, Nobel Yayın Dağıtım, 2010: 45-51.

26. Çakmur H. Araştırmalarda ÖlçmeGüvenilirlik-Geçerlilik. TAF Preventive Medicine Bulletin 2012:11(3).

27. Tezbaşaran A.A. Likert Tipi Ölçek Geliştirme Kılavuzu. Ankara, TPD Yayınları, 1996.

28. Öztürk H., Babacan E. Bir Ölçek Geliştirme Çalışması: Hastanede Çalışan Sağlık Personeli İçin İş Güvenliği Ölçeği.Hemşirelikte Eğitim ve Araştırma Dergisi 2012;9(1):36-42.

29. Dost A., Bahçecik A.N. Hemşirelik Mesleğine Yönelik İmaj Ölçeği Geliştirilmesi. JAREN2015;1(2):51-59. 